ISSN (print): 1698-6180. ISSN (online): 1886-7995

www.ucm.es/info/estratig/journal.htm

Journal of Iberian Geology 38 (2) 2012: 313-330

http://dx.doi.org/10.5209/rev_JIGE.2012.v38.n2.40461

\title{
New Bilbilian (early Cambrian) archaeocyath-rich thrombolitic microbialite from the Láncara Formation (Cantabrian Mts., northern Spain)
}

\author{
Nuevas microbialitas de arqueociatos y trombolitos del Bilbiliense (Cámbrico \\ inferior) de la Formación Láncara (Cordillera Cantábrica, norte de España)
}

\author{
A. Perejón ${ }^{1}$, E. Moreno-Eiris ${ }^{1 *}$, T. Bechstädt ${ }^{2}$, S. Menéndez ${ }^{3}$, M. Rodríguez-Martínez ${ }^{4}$ \\ ${ }^{1}$ Departamento de Paleontología, Facultad de Ciencias Geológicas, Universidad Complutense de Madrid. C/ José Antonio \\ Novais, 12,28040 Madrid,Spain.aparqueo@geo.ucm.es; eiris@geo.ucm.es \\ ${ }^{3}$ Geologisch-Paläontologisches Institut, Ruprecht-Karks -Universität. Im Neuenheimer Feld 234, D-69120 \\ Heidelberg,Germany.bechstaedt@uni-hd.de \\ ${ }^{3}$ Museo Geominero, Instituto Geológico y Minero de España (IGME). C/ Ríos Rosas, 23, 28003 Madrid, Spain \\ s.menendez@igme.es \\ ${ }^{4}$ Departamento de Estratigrafía, Facultad de Ciencias Geológicas, Universidad Complutense de Madrid. C/ José \\ Antonio Novais, 12, 28040 Madrid, Spain.martarm@geo.ucm.es \\ *corresponding author
}

Received: 29/12/2011 / Accepted: 16/06/2012

\begin{abstract}
Recent palaeontological and microfacies studies carried out on the Láncara Formation (early Cambrian) provide evidence for an interesting, previously undescribed association of archaeocyaths (Salce locality) and microbialites (Salce and Barrios de Luna localities). The archaeocyathan assemblage consists of Archaeocyathus laqueus (Vologdin, 1932) and Pycnoidocyathus erbiensis (Zhuravleva, 1955), indicating an early Bilbilian age (Stage 4, Series 2, Cambrian) for these materials. The analysis of the upper part of the lower member has allowed differentiation of eleven carbonate facies that have been grouped into: i) non-skeletal grain packstone-grainstone, ii) fenestral mudstone-packstone, iii) heterolithic stylonodular facies, iv) microbialites, v) bioclast-intraclast packstone-grainstone. Archaeocyaths occur reworked in stylonodular facies as well as forming small archaeocyaths-thrombolitic patches (centimetre-scale). The archaeocyath-rich thrombolitic microbialites from Salce were developed in very shallow subtidal conditions surrounded by other microbialites and small lenticular intertidal bars in the inner ramp. Toyonian biostratigraphic and paleobiogeographic analyses have also been carried out. After the comparison with Toyonian archaeocyathan rich facies from Gondwana, it has become evident that the early Cambrian record from the Cantabrian Mountains provides the richest generic assemblage from Gondwana for Toyonian time.
\end{abstract}

Keywords: Archaeocyaths, Microbialite, Láncara Formation, early Cambrian, Somiedo-Correcilla Subunit, Cantabrian Mountains 


\section{Resumen}

Los recientes estudios paleontológicos y de análisis de microfacies de los materiales carbonatados de la Formación Láncara (Cámbrico inferior) han deparado el hallazgo de una inédita asociación de arqueociatos (localidad de Salce) y microbialitas (localidades de Salce y Barrios de Luna). La asociación de arqueociatos está constituida por Archaeocyathus laqueus (Vologdin, 1932) y Pycnoidocyathus erbiensis (Zhuravleva, 1955), lo que indica una edad Bilbiliense (Piso 4, Serie 2, Cámbrico) para estos materiales. En el análisis de los niveles carbonatados, a techo del miembro inferior, se han distinguido once tipos de facies que han sido agrupadas en: i) packstone-grainstone de granos no esqueléticos, ii) mudstone-packstone con fábrica fenestral, iii) facies estilonodulares heterolíticas, iv) microbialitas, v) packstone-grainstone bioclásticos e intraclásticos. Los arqueociatos aparecen resedimentados en las facies estilonodulares y formando pequeños parches trombolíticos (escala centimétrica). Las microbialitas de arqueociatos y trombolitos de Salce se desarrollaron en condiciones submareales muy someras rodeadas de otras microbialitas y pequeñas barras lenticulares en zonas intermareales de la rampa interna. Se han realizado análisis bioestratigráficos y paleobiogeográficos para el Toyoniense. Tras comparar las facies del Toyoniense ricas en arqueociatos de Gondwana, se manifiesta de manera evidente que el registro del Cámbrico inferior de la Cordillera Cantábrica aporta la asociación genérica más rica de Gondwana durante el Toyoniense.

Palabras clave: Arqueociatos, Microbialitas, Formación Láncara, Cámbrico inferior, Subunidad Somiedo-Correcilla, Cordillera Cantábrica.

\section{Introduction}

The lower-middle Cambrian Láncara Formation (Oele, $1964)$ is mainly composed of dolostone, limestone and occasional shale interbeds, ranging from $150 \mathrm{~m}$ up to 225 $\mathrm{m}$ in thickness (Aramburu et al., 1992). The first stratigraphical and sedimentological analyses of the Láncara Formation were done by Comte (1937), Oele (1964), van der Meer Mohr (1969), Zamarreño and Julivert (1967) and Zamarreño $(1972,1975,1978,1981)$. The relationship between the Láncara Formation and other platforms of the western Gondwana margin was analyzed by Álvaro et al., (2000a), demonstrating that extensive evaporitic conditions were associated with these carbonate and mixed platforms, which were part of an early Cambrian arid subtropical belt.

The Cantabrian Zone records the youngest archaeocyathan biozone in Spain (X Zone, according to Perejón and Moreno-Eiris, 2006a). In fact, the occurrence of archaeocyaths had been previously reported at Esla nappe only. Debrenne and Zamarreño (1970) first described the presence of Archaeocyathus cf. laqueus (Vologdin, 1932) and Pycnoidocyathus cf. erbiensis (ZHURAVLEVA, 1955) at the Valdoré locality. Recently, Álvaro et al., (2000b) also mentioned the occurrence of these taxa at the Crémenes locality. The most recent taxonomic study from these localities was done by Perejón and Moreno-Eiris (2003), who reported the presence of Archaeocyathus laqueus (Vologdin, 1932), Pycnoidocyathus erbiensis (ZhURAvLEVA, 1955), Polythalamia sp. and Okulitchicyathus valdorensis PEREJón and Moreno-EIRIs, 2003. This archaeocyathan assemblage is characteristic of an early Bilbilian or Toyonian age (Spanish and Russian stages respectively). Thus, with the exception of the occurrences in the Láncara Formation at Esla nappe (Crémenes and Valdoré localities), the presence of archaeocyaths at Somiedo-
Correcilla Subunit was unknown.

The purpose of this paper is to: 1) analyze the litho- and biostratigraphic record of Lower Cambrian materials in Salce and its correlation with the closest Barrios de Luna section (reference section for the Láncara Formation in the Somiedo-Correcilla Subunit); 2) reconstruct the environmental setting of the archaeocyath-thrombolitic microbialites from the lower member of the Láncara Formation; 3) document the taxonomy of the archaeocyaths; 4) establish the biostratigraphic and paleogeographic correlations with other regions; and 5) compare the Toyonian archaeocyath-rich biofacies from Gondwana.

\section{Geological Setting and Stratigraphy of the Láncara Formation}

The analyzed occurrence is located in the Cantabrian Zone of the northwestern Iberian Peninsula, in the most external position in the northeastern part of the Iberian Massif (Lotze, 1945) (Fig. 1A). The Cantabrian Zone corresponds to the foreland-and-thrust belt of the northwestern Iberian Variscan Orogen (Julivert, 1971). Orogenic deformation during Carboniferous time resulted in a characteristic thin-skinned tectonic style in the Cantabrian Zone. The Cantabrian Zone has been divided into different tectonostratigraphical units (Vera, 2004; Julivert, 1967; 1971). The present work is focused on Cambrian limestone from the Láncara Formation in the Somiedo-Correcilla Subunit (Julivert et al., 1968), which is part of the Unidades Occidentales y Meridionales [Región de Pliegues y Mantos according to Julivert $(1967,1971)]$, where practically the whole Palaeozoic succession is present. The meridional tract of the Somiedo-Correcilla Subunit (Fig. 1B) comprises the Narcea-Mora, Herrería, Láncara and Oville Formations (Proterozoic to middle Cambrian record, Fig. 2). 
Fig. 1.- A. Simplified geological map of Spain. Shaded box outlines area of B figure. B. Generalised geological map of the Cantabrian Zone modified from Pérez-Estaún et al. (1988). Localities, asterisks: $\mathrm{SAL}=$ Salce, $\mathrm{BL}=$ Barrios de Luna.

Fig. 1.- A. Mapa geológico sintético de España. El recuadro corresponde al área de la figura B. B. Mapa geológico de la Zona Cantábrica modificado de Pérez-Estaún et al. (1988). Localidades, asteriscos: $\mathrm{SAL}=$ Salce, $\mathrm{BL}=$ Barrios de Luna.

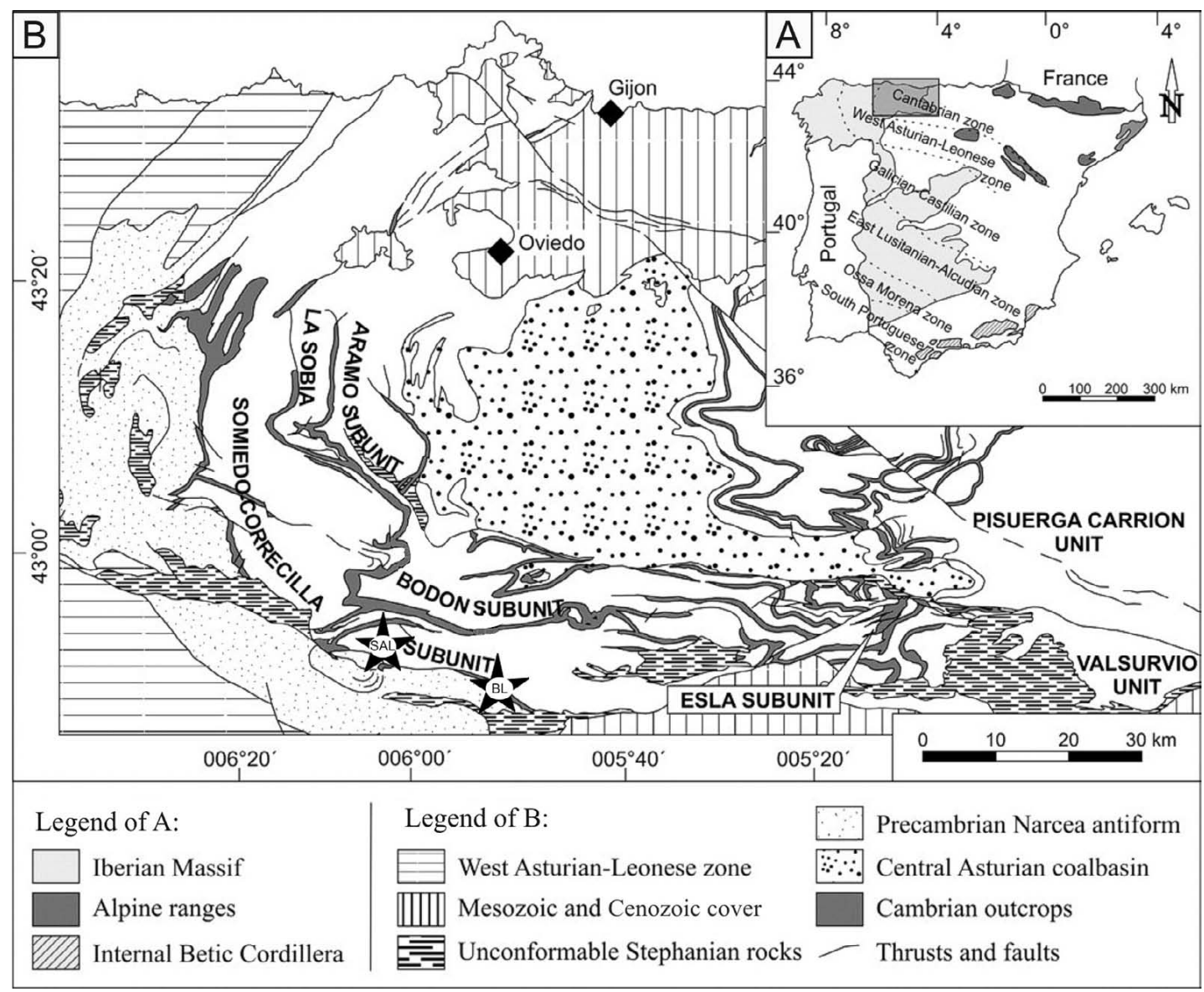

Archaeocyaths have been found at the Salce locality (Perejón et al., 2007) near the Barrios de Luna locality. However the Láncara Formation at Salce is not as well exposed and shows significant differences from the Barrios de Luna section (Fig. 3). To the north of Salce, the Proterozoic and Cambrian rocks are tectonically bounded between two NE-SW faults into a NW-SE nappe structure (MAGNA Sheet 102; Rodriguez Fernández et al., 1990). Along the slopes of Cerro de Valdemarzón, the geological record begins with the siliciclastic rocks of the Narcea-Mora Formation (Neoproterozoic). This is unconformably overlain by sandstone of the Herrería Formation (lower Cambrian), followed by the Láncara Formation carbonates which are in turn conformably overlain by shale of the Oville Formation.

The Láncara Formation was informally divided into two members (lower and upper) by Zamarreño (1972) and displays five distinct units (A-E in Fig. 2), various constituents of which have been named and described by several authors (Zamarreño, 1972, 1978; Álvaro et al., 2000b; Wotte, 2009). The lower member has a variable thickness from $117 \mathrm{~m}$ up to $223 \mathrm{~m}$ whereas the upper member ranges from $11 \mathrm{~m}$ to $48 \mathrm{~m}$ (Aramburu et al., 2006). The lower member exhibits two or three units (A-C in Fig. 2), which according to Zamarreño (1972) correspond to: i) yellow dolostone; ii) grey bedded limestone with birdseyes; and, in some localities, iii) an upper detrital interval up to $12 \mathrm{~m}$ in thickness composed of ooid limestone, sandstone and nodular limestone with archaeocyaths. The upper detrital interval has been recognized in the Esla nappe and at northward of the Esla nappe (Zamarreño, 1978) but has been never described in the Somiedo-Correcilla Subunit. The upper member corresponds to encrinitic-glauconitic limestone and nodulargriotte limestone respectively termed Beleño and Barrios facies by Zamarreño (1972) (D-E in Fig. 2). The present paper describes the first recorded occurrence of archaeocyaths in the Somiedo-Correcilla Subunit at Salce and their lateral equivalents in the nearby Barrios de Luna section; thus carbonate facies descriptions are focused on the upper levels of the lower member of the Láncara Formation.

The top of the Láncara Formation shows three discontinuities (D1-D3 according to Álvaro et al., 2000 b) in the Crémenes and Valdoré sections (Esla nappe). The Salce section records these discontinuities as well, in fact, the archaeocyaths occur in the lenticular limestone (Level 9, Fig. 3) that are bound by the erosive surfaces D1 and D2. The lenticular limestone is succeeded by encrinitic white limestone with trilobites, which marks 


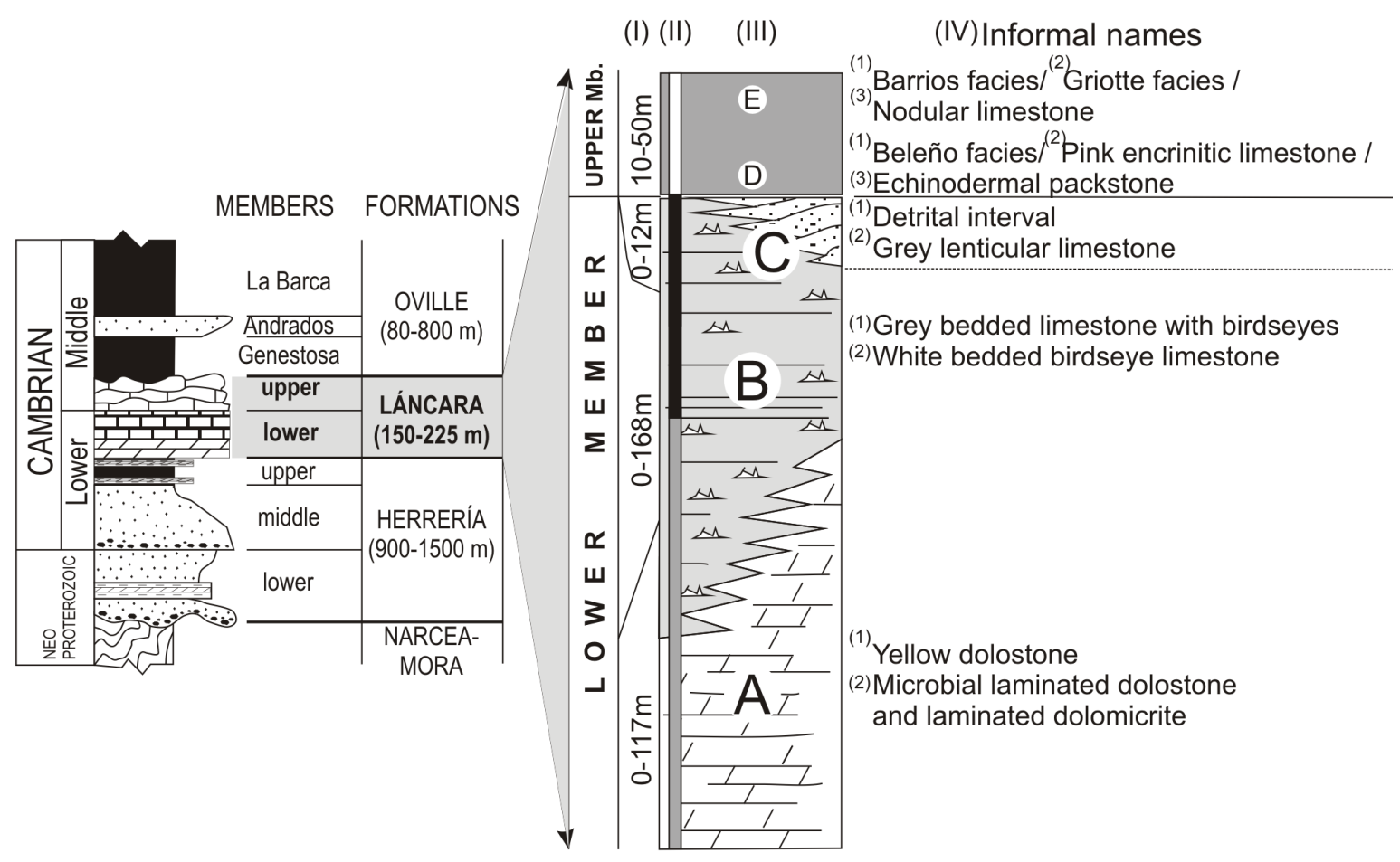

Fig. 2.- General stratigraphy of the Láncara Formation (after Aramburu et al., 1992 and Álvaro et al., 2000b). Distribution of main lithofacies (A-E): (I) Thickness intervals; (II) Black bar represents the analyzed record in this paper; (III) Lithofacies codes; (IV) Informal names assigned to the main lithofacies according several authors: (1) Zamarreño (1972), (2) Álvaro et al. (2000b), (3) Wotte (2009).

Fig. 2.- Sección estratigráfica general de la Formación Láncara (modificado de Aramburu et al., 1992 y Álvaro et al., 2000b). Distribución de las principales litofacies (A-E): (I) Espesores de los intervalos; (II) La barra negra representa el registro estudiado en este trabajo; (III) Códigos de las litofacies; (IV) Nombres informales de las principales litofacies según varios autores: (1) Zamarreño (1972), (2) Álvaro et al. (2000b), (3) Wotte (2009).

the transition from the lower to middle Cambrian. The third discontinuity (D3) occurs between the encrinitic and griotte limestones and is related to a succession of tectonic pulses that have been recognized in other areas in southwestern Europe (Bechstädt et al., 1988; Bechstädt and Boni, 1989; Aramburu et al., 1992; Russo and Bechstädt, 1994; Álvaro and Vennin, 1996). However, in the Barrios de Luna section we have only recognized discontinuities D2 and D3 (Fig. 3).

\section{Carbonate facies}

In the facies analysis we recognize eleven carbonate facies based on the dominance of different components (non-skeletal grains, and skeletal components) as well as the presence of distinct depositional textures and fabrics that can be grouped as: a) non-skeletal grain packstone-grainstone; b) fenestral mudstone-packstone; c) heterolithic stylonodular facies; d) microbialite and archaeocyath-rich thrombolitic microbialite; and e) bioclast- intraclast packstone-grainstone. The facies assemblages from the lower member units (A-C in Fig. 2) have been previously described (see Table 1) by Zamarreño (1972, 1978), Álvaro et al. (2000b), and Wotte (2009).
In this paper the facies analysis is focused on unit B in Barrios de Luna (see Fig. 2 and Table 1) and units B and $\mathrm{C}$ in Salce.

\subsection{Non-skeletal grain packstone-grainstone}

Intraclast-oncoid grainstone (a1) is a poorly sorted fabric dominated by variously shaped small micritic intraclasts (20-35\%) with a wide range of sizes, micritized aggregate grains or lumps (5\%) and oncoids (5-10\%). Oncoids are spheroidal to ellipsoidal, up to $2 \mathrm{~mm}$ in size and formed by concentrically stacked spheroidal layers. Oncoid cortex is composed of micritic, clotted and microsparitic laminae, while the nuclei are bioclasts and intraclasts. This facies (Fig. 4A, facies $a 1$ in Fig. 3 and Fig. 6) can pass abruptly to spongiostromate-oncoid packstonegrainstone. The boundary surface is a sharp, irregular micritized contact where grains may be truncated.

Spongiostromate-oncoid packstone-grainstone (a2) with poorly sorted fabric is conspicuous (Fig. 4B, facies $a 2$ in Fig. 3 and Fig. 6). Spongiostromate oncoid reach up $15 \mathrm{~mm}$ size with a poorly to unlaminated spongy micritic cortex. The term spongiostromate oncoid is used for micrite oncoids possessing a laminated dense micritic or 
spongy fabric without visible filaments (Flügel, 2004). The oncoid nuclei are absent or partially replaced by dolospar mosaic with high content in framboidal pyrite. Oncoids have spheroidal to ellipsoidal shapes and their surfaces are partially eroded. Spongiostromate oncoids represent $25-45 \%$ of rock volume, whereas bioclasts, mainly brachiopods, echinoderms, trilobites and small shelly fossils (SSF), are around $10 \%$. The content of micritic intraclasts fluctuates between $5-10 \%$ of the rock volume.

Intraclast packstone-grainstone and intraclast-bioclast wackestone (a3) (facies $a 3$ in Figs. 3 and 6) occur interbedded with intraclast-oncoid grainstone (facies al) and spongiostromate-oncoid packstone-grainstone (facies a2). Graded bands of moderately sorted packstone-grainstone, dominated by elongated subangular small micritic intraclast (up to $500 \mu \mathrm{m}$ ), are intercalated with massive, poorly sorted intraclast-bioclast wackestone. In the latter case, the intraclasts show a wide range of sizes (but never exceeding $2 \mathrm{~mm}$ ), shapes and orientations.

\subsection{Fenestral mudstone-packstone}

Depositional texture ranges from dense to clotted micritic mudstone up to peloidal intraclast wackestonepackstone. Clotted micritic mudstone is taken here as mudstone composed by microbial peloids with a clotted fabric. In this fabric the microbial peloids are densely packed and forming amalgamated clots surrounded by micrite matrix. In the microfacies peloidal intraclast wackestone-packstone we consider peloid as microbial peloids (Flügel, 2004, 116 p.). Fenestral fabric is well developed and fenestrae show an average size of $0.5 \mathrm{~mm}$ up to $5 \mathrm{~mm}$, forming around $25 \%$ of the rock volume (Fig. 4C, facies $b 1$ and b2 in Fig. 3 and Fig. 6). Fenestrae are concordant to bedding, as well as irregularly oriented. The upper part of the lower member of the Láncara Formation displays irregular laminoid fenestral fabric type b1 and b2 (Tebbutt et al., 1965; Müller-Jungbluth and Toschek, 1969). The type $b 1$ occurs in mudstone (facies b1), while the type $b 2$ is characteristic of wackestonepackstone (facies $b 2$ ). These two depositional textures are vertically arranged in centimetre scale cycles (1-5 $\mathrm{cm}$ ) in metre scale beds and occur interstratified with microbialitic facies. The fenestral mudstone-packstones are partially dolomitized, forming coarsening upwards cycles from fine-grained to grain-supported fabrics. Larger fenestrae occur at the base, however, the connectivity between fenestrae increases towards the top together with the degree of dolomitization.

\subsection{Heterolithic stylonodular facies (pelletoid grainstone; archaeocyathan wackestone and dolosparitic nodules)}

This lithofacies assemblage occurs at the top of the lower member of the Láncara Formation and displays massive to stylonodular structure with irregular anastomosing

\begin{tabular}{|c|c|c|c|c|}
\hline \multirow{2}{*}{$\begin{array}{l}\text { Lithofacies } \\
\text { (codes from } \\
\text { Fig. 2) }\end{array}$} & Zamarreño $(1972,1978)$ & Álvaro et al., (2000b) & Wotte (2009) & This paper \\
\hline & Several localities & Crémenes and Valdoré & $\begin{array}{c}\text { Crémenes }^{(1)} \text { and Barrios de } \\
\text { Luna }^{(2)}\end{array}$ & Barrios de Luna ${ }^{(2)}$ and Salce ${ }^{(3)}$ \\
\hline $\mathrm{C}$ & $\begin{array}{l}\text { Oosparite; sandstone; } \\
\text { nodular limestone with } \\
\text { archaeocyaths }\end{array}$ & $\begin{array}{l}\text { Ooidal to bioclastic } \\
\text { grainstone; } \\
\text { sandy channels; } \\
\text { archaeocyathan- } \\
\text { microbial reefs; hyolith- } \\
\text { rich wakestone }\end{array}$ & $\begin{array}{l}\text { Oolitic bioclastic floatstone } \\
\qquad(\mathrm{L} 7)^{(1)}\end{array}$ & $\begin{array}{l}\text { Archaeocyath-rich thrombolitic } \\
\text { microbialite }^{(3)} \text {; bioclast-intraclast } \\
\text { packstone-grainstone }{ }^{(3)} ; \\
\text { archeocyath wackestone and } \\
\text { dolosparitic nodules }^{(3)} ; \text { pelletoid } \\
\text { grainstone }^{(3)}\end{array}$ \\
\hline B & $\begin{array}{l}\text { Grey bedded limestone } \\
\text { with birdseyes; algal } \\
\text { mats; stromatolites; } \\
\text { intrapelsparrudite }\end{array}$ & $\begin{array}{l}\text { Fenestral, peloidal and } \\
\text { microbial grainstone; } \\
\text { ooidal grainstone; } \\
\text { bioclastic wackestone to } \\
\text { mudstone }\end{array}$ & $\begin{array}{l}\text { Non-laminated (L6) })^{(1,2)} \text { and } \\
\text { laminated (L5) })^{(2)} \text { aggregated } \\
\text { grainstone; laminated } \\
\text { mudstone (L3) })^{(1,2)} \text {; claystone } \\
\qquad(\mathrm{L} 1)^{(1,2)}\end{array}$ & 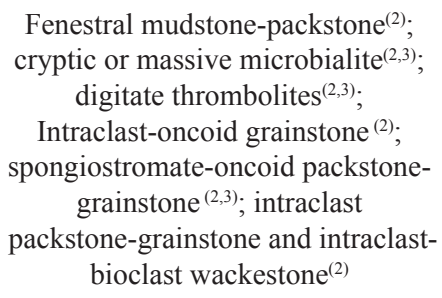 \\
\hline $\mathrm{A}$ & $\begin{array}{c}\text { Massive and } \\
\text { laminated dolomicrite; } \\
\text { pelsparite; pelsmicrite; } \\
\text { intrapelsparite; oosparite; } \\
\text { cryptalgal laminites }\end{array}$ & & $\begin{array}{l}\text { Recrystallized mudstone } \\
(\mathrm{L} 2)^{(2)} \text {; oolitic bioclastic } \\
\text { floatstone (L7) })^{(2)} \text {; laminated } \\
\text { mudstone with laminoid } \\
\text { fenestral fabrics (L4) } \\
\quad \text { stromatolites }^{(2)}\end{array}$ & \\
\hline
\end{tabular}

Table 1.- Lithofacies assemblages in the lower member of the Láncara Formation according to several authors.

Tabla 1.- Asociaciones de facies del miembro inferior de la Formación Láncara según diferentes autores. 


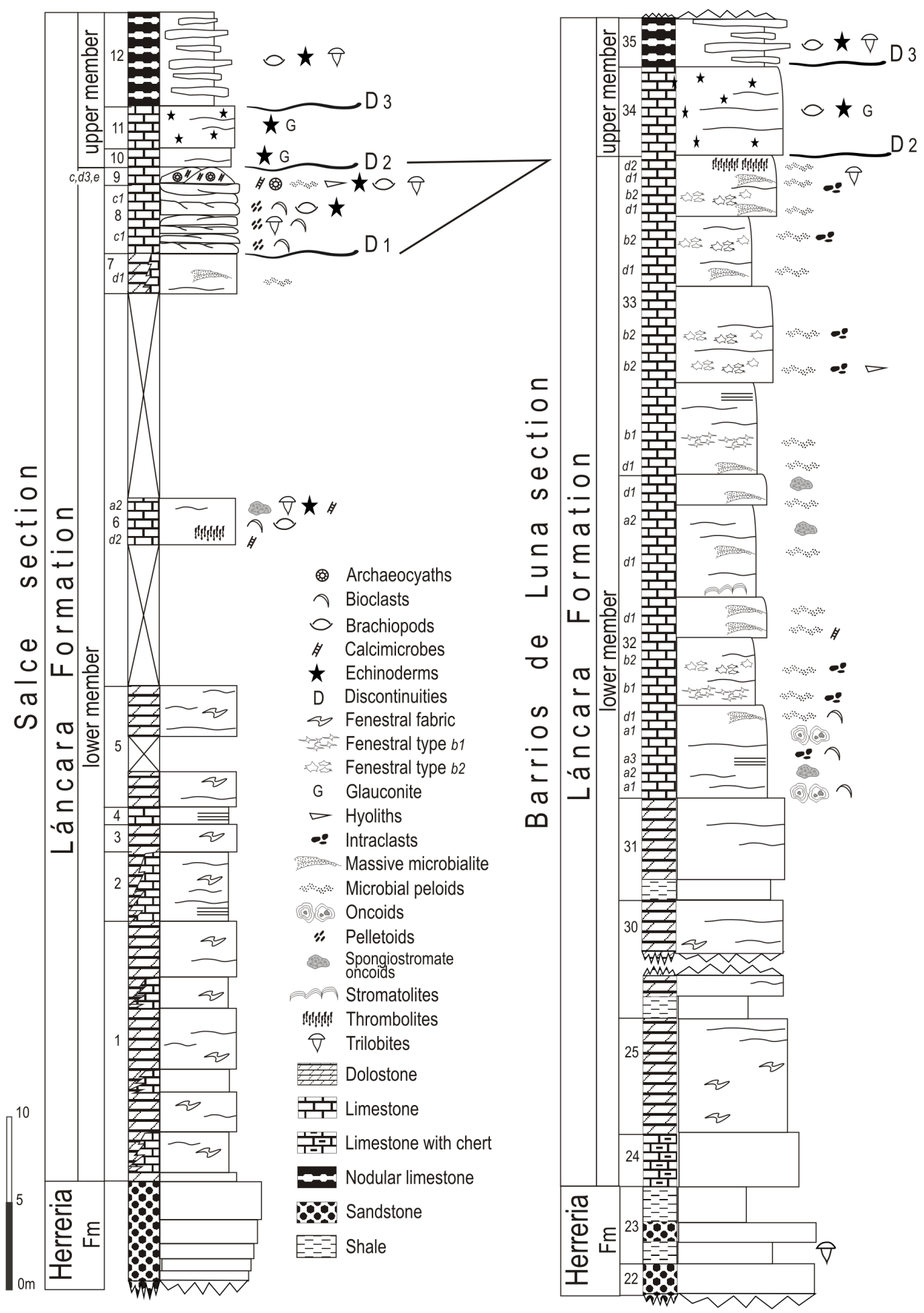

Fig. 3.- Stratigraphic sections from localities Salce (left) and Barrios de Luna (right).

Fig. 3.- Columnas estratigráficas de las localidades de Salce (izquierda) y Barrios de Luna (derecha).

sets (pressure-solution structures).

Pelletoid grainstone (c1) displays massive fabric at the base and are mainly composed of very well sorted, round to elongated, recrystallized micritic grains or pelletoids (Flügel, 2004, 112 pp) with vague residual internal structures and diffuse margins, and sizes between $200 \mu \mathrm{m}$ and
$500 \mu \mathrm{m}$. Pelletoid volume can reach $55 \%$ of rock volume (facies $\mathrm{c} 1$ in Fig. 4D, Figs. 3 and 6). The bioclast content ranges between $5 \%$ and $10 \%$ and consists of brachiopods, echinoderm plates, trilobites and reworked fragments of archaeocyaths (Fig. 7H). Where the bioclast content is low, shells are oriented parallel to bedding, whereas a 
greater proportion of bioclasts shows an irregular distribution of orientations that is linked to the presence of intraclasts, cortoids and reworked spongiostromate oncoids.

Archaeocyath wackestone and dolosparitic nodules (c2) show a stylonodular structure (Logan and Semeniuk 1976). Archaeocyath wackestone are nodules composed of reworked archaeocyaths, scattered bioclasts and partially dolomitized matrix (facies c2 in Figs. 5A, 6, 7A and $7 \mathrm{~B}$ ), whereas the centimeter to decimeter scale dolosparitic nodules are formed by inequigranular hypidiotopic dolomite.

The vertical arrangement of this lithofacies assemblage starts with massive pelletoid grainstone beds which grade into interbedded stylonodular levels where the nod- ules are composed of pelletoid grainstone, achaeocyath wackestone and dolospar. Detrital quartz grains (sand to silt size) occur as accessory to minor component dispersed within nodules and also concentrated in the stylolaminated intervals

\subsection{Microbialites}

Microbialite is taken here sensu Burne and Moore (1987, p. 241-242) as organosedimentary deposits that have accreted as a result of benthic microbial community trapping and binding detrital sediment and/or forming the locus of mineral precipitation. The microbialites in the upper part of the lower member of the Láncara For-
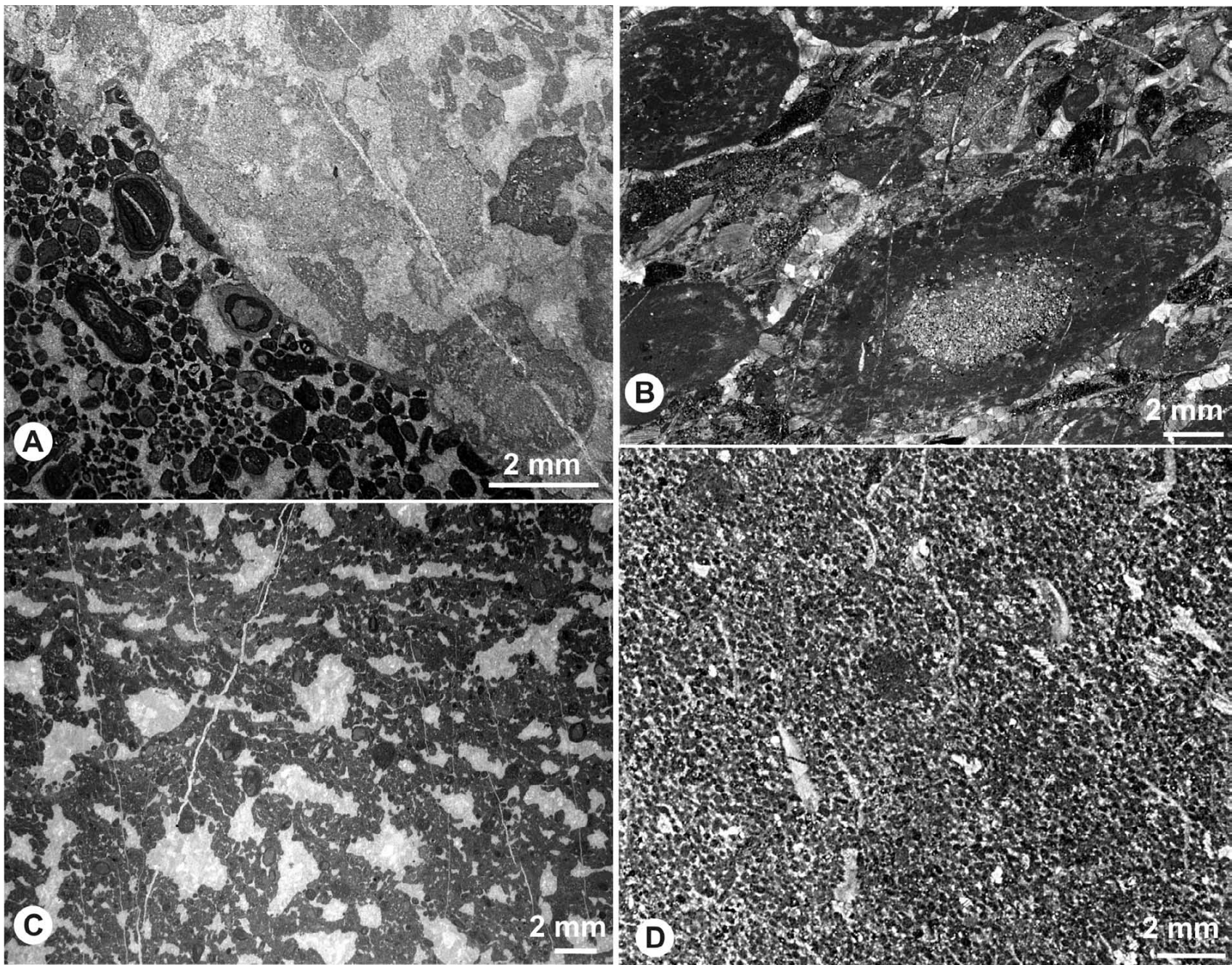

Fig. 4.- Carbonate microfacies from the upper part of the lower member of the Láncara Formation (see also Figure 5). A. Irregular truncated boundary (short omission surface in high-energy conditions) between intraclast-oncoid grainstone (facies $a 1$, bottom left) and very recrystallized spongiostromate oncoid grainstone (facies a2). BL1-32A. B. Detail of spongiostromate oncoids. SAL6/4a. C. Irregular laminoid fenestral fabric type $b 2$. BL1-32E. D. Pelletoid grainstone (facies $c 1$ ). The bioclasts are oriented parallel to the bedding surface. SAL8/2

Fig. 4.- Microfacies carbonatadas a techo del miembro inferior de la Formación Láncara (ver también Figura 5). A. Contacto irregular (superficie de omisión y con carácter erosivo desarrollada en condiciones de alta energía) entre un grainstone intraclástico-oolítico (facies al, abajo izquierda) y un grainstone oncolítico spongiostromata muy recristalizado (facies a2). BL1-32A. B. Detalle de oncolitos tipo spongiostromata. SAL6/4a. C. Fábrica fenestral laminoide irregular tipo b2. BL1-32E. D. Grainstone de pelletoides (facies $c 1$ ). Los bioclastos están orientados paralelos a la superficie de estratificación. SAL8/2. 


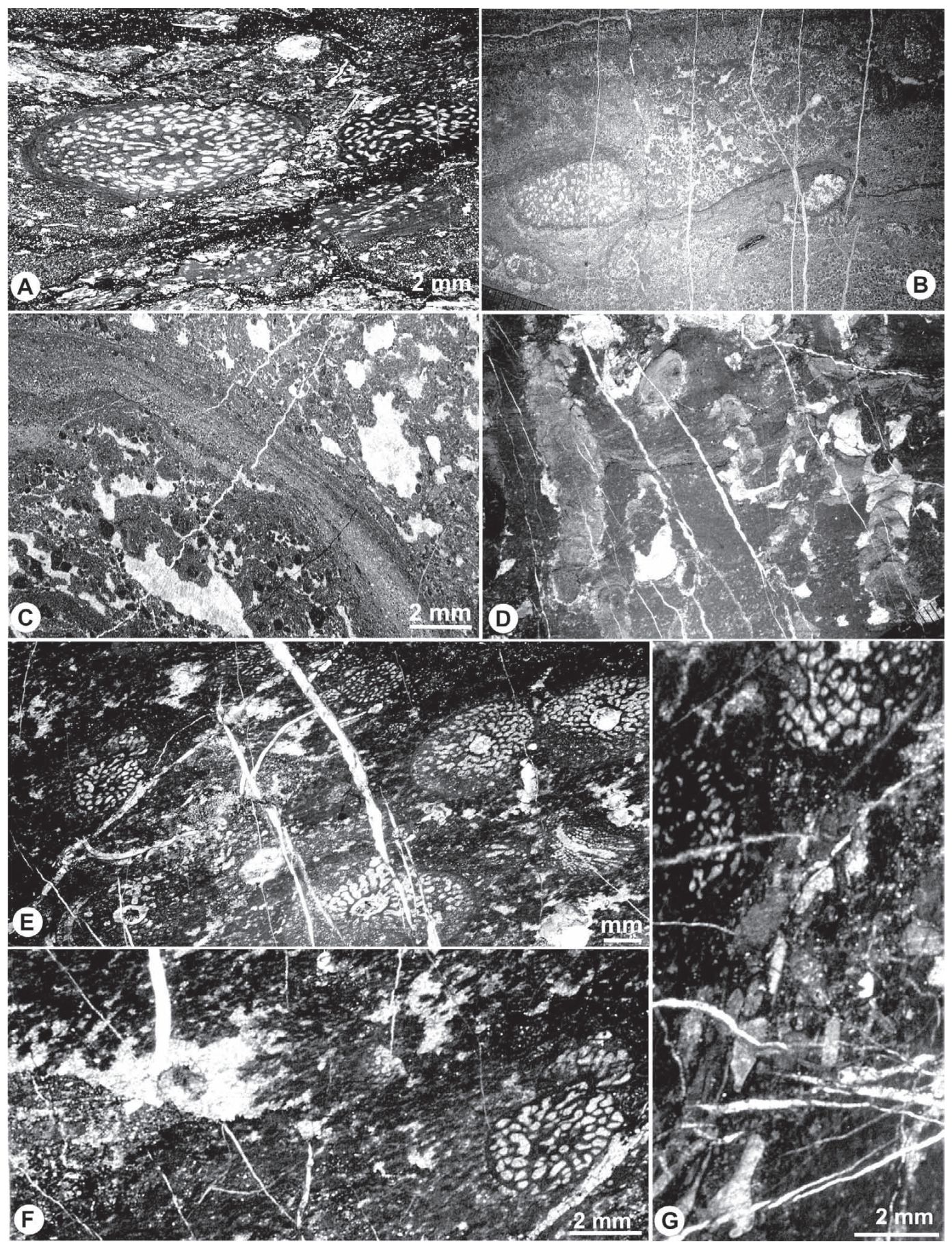

Fig. 5.- Carbonate microfacies from the upper part of the lower member of the Láncara Formation. A. Archaeocyath wackestone with stylonodular fabric. SAL9/1-1. B. Massive peloidal microbialite. Note the presence of peloidal crusts binding spongiostromate oncoids. Scale divisions correspond to $0.5 \mathrm{~mm}$. BL2/233A. C. Laminated peloidal crust binding fenestral wackestone-packstone. BL1/33D. D. Columnar mesoclots of a digitate thrombolite. Scale divisions correspond to $0.5 \mathrm{~mm}$. (E-G) Archaeocyath-rich thrombolitic microbialite. SAL6/1. E. General view of archaeocyaths surrounded by dense dark clotted micrite. SAL/1-1a. F. Stromatactoid cavity with branching, shrub-like forms of Epiphyton on the ceiling. SAL/1-1b. G. Bioclast pocket mostly composed of echinoderm remains and quartz silt grains. SAL/5-2. (A, E-G) Archaeocyathus laqueus (Vologdin, 1932) are present.

Fig. 5.- Microfacies carbonatadas a techo del miembro inferior de la Formación Láncara. A. Wackestone de arqueociatos con fábrica estilonodular por presión-disolución. SAL9/1-1. B. Microbialita peloidal masiva. Nótese la presencia de costras peloidales encostrando oncoides de tipo spongiostromata. Cada división de la escala corresponde a $0.5 \mathrm{~mm}$. BL2/233A. C. Costras peloidales laminadas encostrando wackestone-packstone fenestrales. BL1/33D. D. Mesoclots columnares de un trombolito digitado. Cada división de la escala corresponde a $0.5 \mathrm{~mm}$. (E-G) Microbialita trombolítica rica en arqueociatos. SAL6/1. E. Vista general de arqueociatos rodeados de de fábricas densas y oscuras de tipo 'clotted micrite'. SAL/1-1a. F. Cavidad estromatactoidea con formas arborescentes y ramosas de Epiphyton en el techo. G. Acumulación de bioclastos compuesta mayoritariamente por restos de equinodermos y granos de cuarzo. SAL/5-2. (A, E-G) Los cálices que aparecen son Archaeocyathus laqueus (Vologdin, 1932). 
mation show three different mesostructures (scales of observation following Shapiro, 2000): i) cryptic or massive microbialite; ii) digitate thrombolite (sensu Aitken, 1967); and iii) archaeocyath-rich thrombolitic microbialite and spongiostromate-oncoid peloidal microbialite.

Cryptic or massive microbialite (d1) are built up by a mosaic of peloidal fabrics, forming massive homogeneous coarse-peloidal patches or pockets as well as wavy to irregular laminated peloidal crusts (Fig. 5B, facies $d l$ in Fig. 3 and Fig. 6). The microbial peloids have an average size of $60 \mu \mathrm{m}$. The massive homogeneous coarse peloidal patches are similar to those microstructures described as Spongiostroma ovuliferum and Chondrostroma problematicum by Gürich (1906) from Visean material. The peloidal laminated crusts possess accessory detrital quartz silt and encrust spongiostromate oncoids (Fig. 5B) as well as patches of peloid- intraclast wackestone-packstone with irregular laminoid fenestral fabric (Type b2) (Fig. 5C).

Digitate thrombolite (d2) is composed of minicolumnar mesoclots 1-3 $\mathrm{mm}$ wide and up to $20 \mathrm{~mm}$ high (Fig. 5D, facies $d 2$ in Fig. 3 and Fig. 6). The microstructure of mesoclots corresponds to massive to crudely laminated microspar. The intercolumnar space is filled by massive dense to peloidal micrite intervals covered by finely laminated intervals that laterally link the minicolumnnar mesoclots. These laminated intervals are composed of alternating microsparitic and dense micritic laminae. In some cases, the microstructure of mesoclots is well preserved, showing their peloidal character and finely laminated dense micrite. The digitate thrombolites occur associated with spongiostromate-oncoid packstone (a2) and commonly with cryptic or massive microbialite (d1). Archaeocyath-rich thrombolitic microbialite (d3) comprises small lenticular patches (up to $15 \mathrm{~cm}$ high and around $20 \mathrm{~cm}$ wide) formed by densely packed dark mesoclots (up to $40 \%$ of rock volume) surrounding small branched colonies of archaeocyaths, which constitute $25 \%$ of the rock volume (Fig. 5E, facies $d 3$ in Figs. 3 and 6). The main genus is Archaeocyathus. The microstructure of mesoclots is partially recrystallized, but still displays branching, shrub-like forms of Epiphyton. Dense patches of mesoclots are the dominant fabric and the occurrence of hyoliths is sporadic. Cavities do not exceed $10 \%$ and show stromatactoid shapes with flat bases and irregular roofs. They are about $5 \mathrm{~mm}$ wide and are filled by internal sediment and prismatic and equant calcite cements, now partially recrystallized (Fig. 5F). Clusters of mesoclots also occur pendent from cavity roofs and encrusting the outer walls of archaeocyaths. The encrustations around them are asymmetric, showing a preferential growth direction, indicating current influence during accretion. Intermesoclot spaces are filled by peloidal mic- rite (10-20\%) and recrystallized, partially dolomitized micrite with quartz silt. There are pockets of bioclast packstone with eocrinoid arm plates (up to 5\%), plus brachiopod and trilobite fragments (Fig. 5G).

Archaeocyath-rich thrombolitic microbialite occurs at the top of the lower member of the Láncara Formation at Salce. It is laterally gradational into pelletoid-intraclast grainstone $(c 1)$ and bioclast-intraclast grainstone $(e)$ (Figs. 7E and 7F). This lateral change is irregular and locally abrupt. In other cases, archaeocyath-rich thrombolitic microbialite grades into spongiostromate-oncoid peloidal microbialite (d3), which are gradually overlain by pelletoid-bioclast grainstone $(c 1)$. The spongiostromate-oncoid peloidal microbialite is composed of $40 \%$ spongiostromate oncoids, parautochthonous archaeocyaths $(10 \%)$ and hyoliths (5\%), all surrounded by homogeneous fine peloidal micrite $(40 \%$ of the rock volume -microbial peloids up to $40 \mu \mathrm{m}$ in size). Shelter porosity associated with spongiostromata oncoids and archaeocyaths represents around $10 \%$ of rock.

\subsection{Bioclast- intraclast packstone-grainstone}

Bioclast-intraclast packstone-grainstone (e) occurs surrounding the patches of archaeocyath-rich thrombolitic microbialite (Figs. 3 and 6). It is characterized by a poorly sorted fabric with high skeletal content, up to $25 \%$ of rock volume with remains of brachiopods, echinoderms, trilobites and archaeocyaths. Intraclasts are conspicuous and their internal fabric shows clotted textures resembling those observed in mesoclots from archaeocyath-rich thrombolite. Pelletoids can attain up to $10-15 \%$ of rock volume and spongiostromate oncoids are accessory components.

\section{Environmental setting of archaeocyath-rich thrombolitic microbialites}

The lower member of the Láncara Formation shows sedimentary and paleontological features linked to tidal plain environments (Zamarreño, 1972, 1975; Aramburu et al., 1992) developed in a homoclinal ramp (Aramburu, 1989). The upper part of the lower member is characterized by the occurrence of non-skeletal grain-rich facies, fenestral mudstone-packstone and microbialites (Fig. 6), whereas skeletal-rich facies are minor deposits. The microbial activity was significant and widespread, forming several types of structures (massive and microlaminated peloidal fabric, stromatolites, thrombolites, calcimicrobial remains), and was also linked to the formation of such non-skeletal grains as spongiostromate oncoids and microbial peloids (Flügel, 2004). Spongiostromate oncoids 

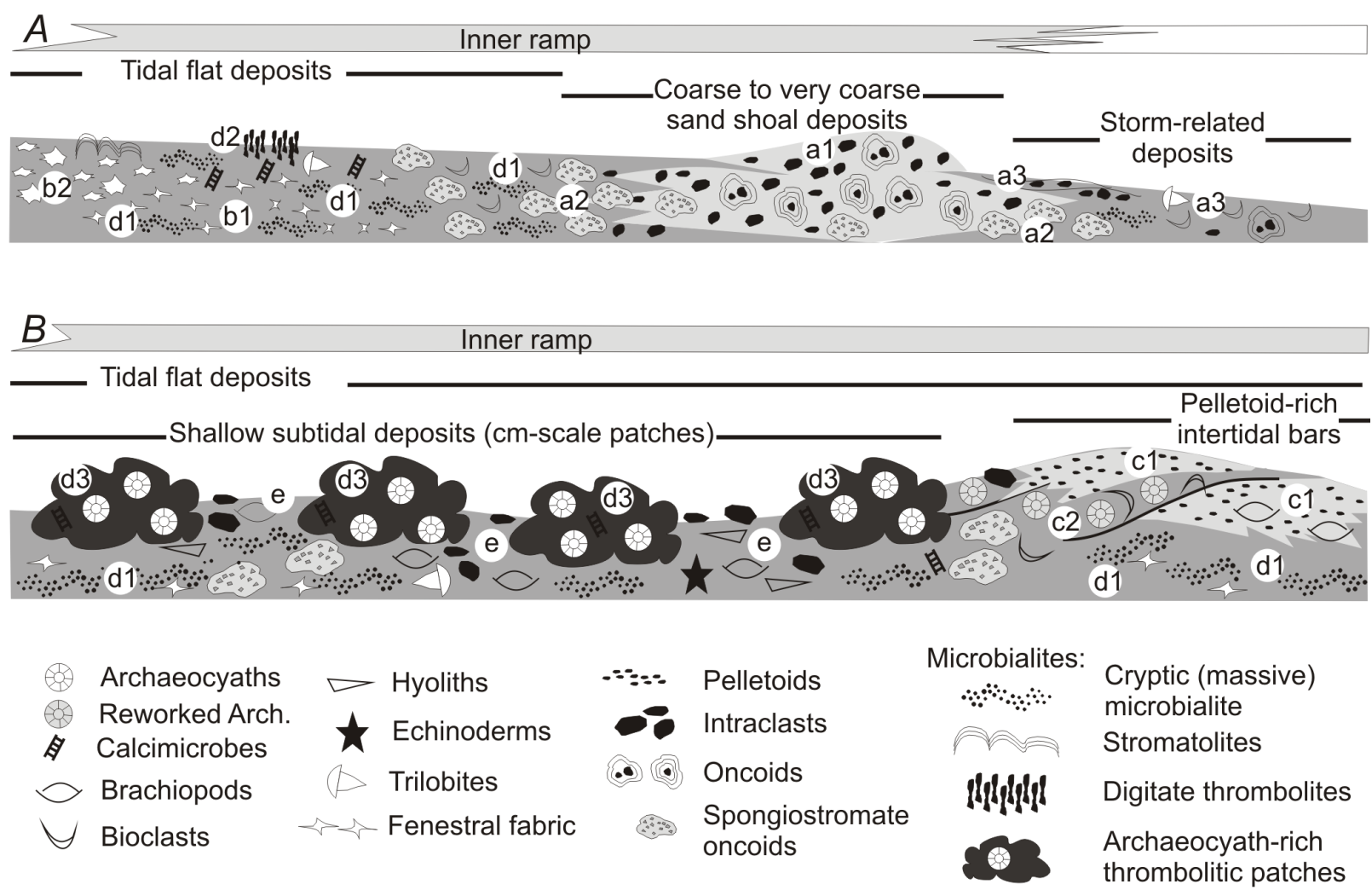

Fig. 6.- Depositional model for the upper part of the lower member of the Láncara Formation showing the distribution of skeletal and non-skeletal components. A Barrios de Luna (32 and 33 intervals in Figure 3) and B Salce (7-9 intervals in Figure 3) localities: (a1) Intraclast-oncoid grainstone; (a2) Spongiostromate oncoid packstone-grainstone; (a3) Graded intraclast grainstone and massive intraclast-bioclast wackestone; (b1) Mudstone with irregular laminoid fenestral fabric; (b2) Wackestone-packstone with irregular laminoid fenestral fabric; (c) Heterolithic stylonodular facies: (c1) Pelletoid grainstone, and (c2) Archaeocyath wackestone nodules and dolosparitic nodules; $(d 1)$ Massive microbialites; $(d 2)$ Digitate thrombolites; $(d 3)$ Archaeocyath-rich thrombolitic patches; $(e)$ Bioclast-intraclast packstone-grainstone.

Fig. 6.- Modelo deposicional de facies mostrando la distribución de los componentes esqueléticos y no esqueléticos de la parte superior del miembro inferior de la Formación Láncara. Localidades Barrios de Luna (A, tramos 32 y 33 en Figura 3) y Salce (B, tramos 7-9 en Figura 3): (al) Grainstone intraclástico-oncolítico; (a2) Packstone-grainstone de oncolitos tipo Spongiostromata; (a3) Grainstone intraclástico gradado y wackestone intraclástico-bioclástico masivo; (b1) Mudstone con fábrica fenestral laminoide irregular; (b2) Wackestone-packstone con fábrica fenestral laminoide irregular; (c) Facies nodulares heterolíticas: (cl) Grainstone de pelletoides, y (c2) nódulos wackestone con arqueociatos y nódulos doloesparíticos; (d1) Microbialitas masivas; (d2) Trombolitos digitados; (d3) Parches trombolíticos ricos en arqueociatos; (e) Packstone-grainstone bioclástico-intraclástico.

occur mostly in lacustrine and transitional marine environments and they are commonly associated with stromatolites in settings with a relatively fast rate of deposition (Peryt, 1981). Spongiostromate oncoids exhibit a great variety of microstructures but cyanobacterial remains are unrecognizable because of their rapid transformation (Krumbein and Cohen, 1977).

Grain-dominated lithofacies are local in the upper part of the lower member (Fig. 6) and correspond to: i) poorly sorted fabrics generated by high-energy sedimentation as intraclast-oncoid shoals (a1-a2), ii) graded storm deposits (a3), and iii) very well sorted, pelletoid-rich, lenticular (centimetre scale), intertidal bars $(c l)$. On the contrary, the typical and most extended facies assemblage is formed by massive to fenestral mudstone-packstone ( $b 1$ and $b 2$ ) and microbialites $(d)$. Fenestral fabrics are characteristic structures in peritidal environments and they have been related to degassing of decaying organic matter, gas bubbles, burrowing, soft-deformation, wetting and drying of carbonate mud in supratidal environments (Shinn, 1968), and drying of cyanobacterial mats (Davies, 1970) as they commonly occur in association with microbial mats and microbialites.

The patches of archaeocyath-rich thrombolitic microbialites ( $d 3$ in Fig. 6) occur only at Salce, surrounded by massive microbialites $(d l)$ and small, lenticular, pelletoid-rich intertidal bars $(c l)$. Between the small centimeter-scale patches, filter feeders increase $(e)$, reflecting more suitable conditions for colonization of substrate by a diverse benthic biota such as brachiopods, trilobites, echinoderms and hyoliths. Archaeocyathan microbialites occur also at the Esla nappe at Crémenes 


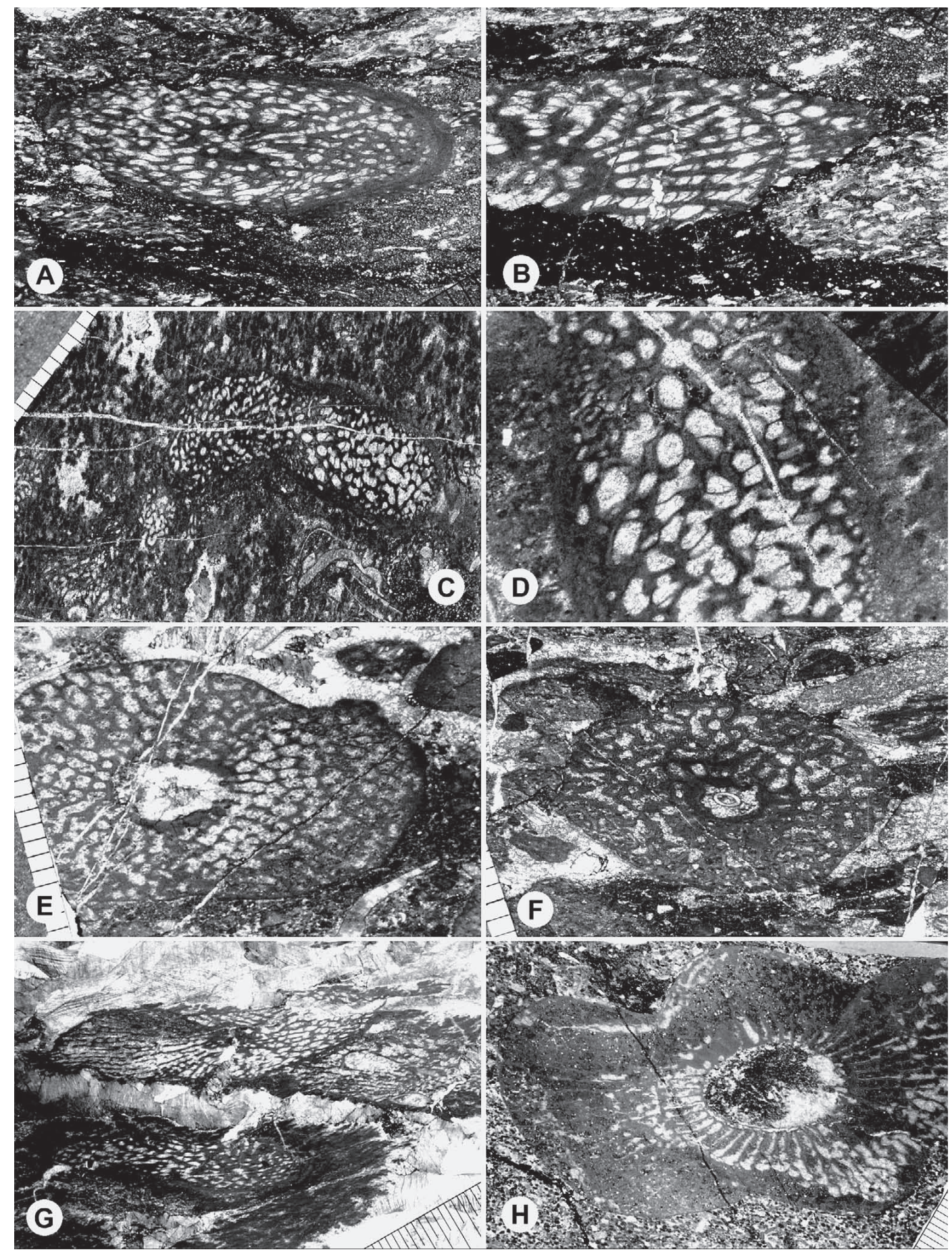

Fig. 7.- (A-G) Archaeocyathus laqueus (Vologdin, 1932). A. Oblique transverse section. SAL9/1-1. B. Oblique transverse section. SAL9/1-3. C-D. Specimen SAL/1-2/9. C. Longitudinal section. D. Same, detail of the outer wall. E. Transverse section. SAL/3-1/1. F Transverse section. SAL/1-4/1. G. Oblique transverse and longitudinal sections of two cups. SAL/3-3. H. Pycnoidocyathus erbiensis (Zhuravleva, 1955). Transverse section. SAL9/4-2/1. Scale division $0.5 \mathrm{~mm}$.

Fig. 7.- (A-G) Archaeocyathus laqueus (Vologdin, 1932). A. Sección transversal oblicua. SAL9/1-1. B. Sección transversal oblicua. SAL9/1-3. C-D. Especimen SAL/1-2/9. C. Sección longitudinal. D. Detalle de la muralla externa del mismo ejemplar. E. Sección transversal. SAL/3-1/1. F. Sección transversal. SAL/1-4/1. G. Secciones transversal oblicua y longitudinal de dos cálices. SAL/3-3. H. Pycnoidocyathus erbiensis (ZhURAVleVA, 1955). Sección transversal. SAL9/4-2/1. Cada división de la escala equivale a 0.5 mm.

and Valdoré. They appear as small mounds up to $0.5 \mathrm{~m}$ thick and $1.2 \mathrm{~m}$ wide, growing interbedded with ooid and bioclast grainstone, with high siliciclastic input. These meter-sized bioherms grew in shallow-water, protected back-shoal environments, which offered suitable conditions of stability and lack of significant bottom currents (Debrenne and Zamarreño, 1970; Álvaro et al., 2000b; Perejón and Moreno-Eiris, 2003). Crémenes and Valdoré 
mounds are also characterized by branching colonies of Archaeocyathus laqueus (Vologdin, 1932), as observed at Salce. However, the calcimicrobes are best preserved at Crémenes and Valdoré, where archaeocyaths appear colonized by thick envelopes of Renalcis, Epiphyton and Girvanella. The archaeocyathan biodiversity in the Esla nappe is higher because the floatstone lithofacies surrounding the mounds records the presence of Polythalamia sp., and Okulitchicyathus valdorensis PEREJón and Moreno-Eiris, 2003 (Debrenne and Zamarreño, 1970; Perejón and Moreno-Eiris, 2003). In the Somiedo-Correcilla Subunit and the Esla nappe, the occurrence of $P y c$ noidocyathus erbiensis (ZHURAVLEVA, 1955) is linked to the surrounding muddy facies and not to the microbialitic frameworks.

\section{Systematic paleontology}

Phylum Porifera Grant, 1836

Class Archaeocyatha Bornemann, 1884

Order Archaeocyathida Okulitch, 1935

Suborder Archaeocyathina Okulitch, 1935

Superfamily Archaeocyathoidea Hinde, 1889

Family Archaeocyathidae Hinde, 1889

Genus Archaeocyathus Billings, 1861

Type species: Archaeocyathus atlanticus Billings, 1861

Diagnosis: Cups with centripetal outer wall; inner wall with one row of pores per intersept, bearing, upwardly projecting pore tubes; coarsely porous pseudotaenial network; centripetal segmented tabulae (Debrenne et al., 2002).

Archaeocyathus laqueus (Vologdin, 1932)

Figures 5 A, E-G, 7 A-G

1932 Retecyathus laqueus Vologdin. p. 20-21; P1. II, fig. $5 \mathrm{v}$ y 6-8; Fig. 14a.

1937 Retecyathus laqueus Vologdin. Vologdin, p. 458; P1.

I, fig. 2.

1940 Retecyathus laqueus Vologdin. Chi, p.135; Pl. III, fig. 1-2.

1940 Retecyathus laqueus Vologdin. Vologdin, p. 44; P1.

IV, fig. 1-2; Fig. 17.

1960 Archaeocyathus laqueus (Vologdin). Zhuravleva, p. 298.

v 1970 Archaeocyathus cf. laqueus (Vologdin). Debrenne \& Zamarreño, p. 7-9, Fig. 5.

1985 Archaeocyathus laqueus (Vologdin). Debrenne \&

Gandin, p. 538; P1.II, fig. 4.

1985 Retecyathus laqueus Vologdin. Fonin, p. 70-71; Pl.

I, fig. 1-4.
1992 Archaeocyathus cumfundus? (Vologdin). Debrenne \& Zhuravlev, p. 120.

v 2003. Archaeocyathus laqueus (Vologdin, 1932). Perejón \& Moreno-Eiris, p. 56-58; Fig. 3. Lám. III, figs. 1-3; Lám. IV, figs. 1-4; Lám. V, fig. 1 a.

Holotype. Not designated.

Lectotype. A. G. Vologdin, 1932, p. 20, Lám. II, figs. 6,7; Fig. 14a, Altai, Karagan River. Lower Cambrian (Fonin, 1985, p. 70).

Material. 38 thin sections.

Diagnosis amended. Species of genus Archaeocyathus usually with a modular habit, forming branching colonies by budding. Central cavity narrow, sometimes non-existent and occupied by vesicular tissue and thickened interval elements. The presence of vesicular tissue determines the thickening of the taeniaes (stereoplasma).

Description. Cups small, solitary or modular with a variable number of individuals. In the youngest branches and basal areas of the cups the outer wall is imperforate, and in adults it has centripetal porosity. Intervalllum occupied by warped taeniae with large pores, sometimes thickened and linked by synapticulae and vesicular tissue, which can be very abundant. In many sections of small diameter, the interval presents alveolar structure and only in cups of larger diameter do taeniae have a clearly radial development. The inner wall has one pore per intertaenia, bearing a projecting short tube, although in many sections this wall is not well defined. The central cavity is small and in many cups does not exist, in these cases the space is occupied by intervallar elements and vesicular tissue. In some sections exocyathoids buttresses are developed on the outer wall.

Dimensions in mm. Cup: D 1.52 to14.22; I 0.44 to 1.91 ; ds 0.12 to 0.63 ; IK 0.50 to 0.34 ; IC variable. Outer wall centripetal: d 0.06 ; i 0.03 ; e 0.03 . Inner wall: $\mathrm{n} 1$; d 0.12 to 0.25 ; i 0.08 to 0.12 ; e 0.04 to $0.12-0.20$. Taeniae: $\mathrm{n} 4$ to 6 ; $\mathrm{d} 0.24 \times 0.12$ to $0.36 \times 0.42$; i 0.04 to 0.12 ; e 0.04 to 0.12 . Synapticulae: e 0.04 to 0.08 .

Discussion. The abundant material is assigned to the species A. laqueus (Vologdin) on the basis of the similar structure of the cups in which the dimensions and ratios are consistent with the limits of variability of the species described in other similarly-aged locations in the Cantabrian Mountains. For further observations and a more complete discussion see Perejón and Moreno-Eiris (2003).

Geographic and stratigraphic distribution. RussiA: Western Sayan, Kazilik River; East Sayan, Kazyr River, Tuva, Irbitei River; Altirgani, Altai, Karagan River. 
Obruchev Horizon, Toyonian, Lower Cambrian. Kuznetsk Alatau, Bol'shaya Erba; Western Sayan, Malyy Karakol River; Tuva, Ulug-Shang River. Kameshki and Sanashtykgol Horizons, Late Atdabanian, Early Botomian, Lower Cambrian. China: Hubei Province. Shihlungtung limestone. Lower Cambrian. ItaLY: Sardinia. Brèche Acquaresi, Onixeddu Mountain. Gonnesa Formation, Toyonian, Lower Cambrian. SpaIN: Valdoré, Crémenes (Esla nappe) and Salce (Somiedo-Correcilla Subunit), Cantabrian Mountains. Láncara Formation, Early Bilbilian (Zone X), Stage 4, Series 2, Cambrian.

Genus Pycnoidocyathus Taylor, 1910

Type species: Pycnoidocyathus synapticulosus Taylor, 1910.

Diagnosis. Cups with centripetal outer wall; inner wall with one row of pores per intersept, bearing straight, upwardly projecting pore tubes; coarsely porous taeniae linked by synapticulae at the base, taeniae becoming progressively less porous, more planar and without synapticulae (Debrenne et al., 2002).

Pycnoidocyathus erbiensis (Zhuravleva, 1955)

Figure $7 \mathrm{H}$

1955 Archaeocyathus erbiensis Zhuravleva. Zhuravleva, p. 20, Fig. 1.

1964 Archaeocyathus erbiensis Zhuravleva. Repina et al., p. 241, Pl. 30, fig. 5.

1967 Flindersicyathus cf. erbiensis (Zhuravleva).

Zhuravleva et al. p. 96, P1. 51, fig. 7.

v 1970 Pycnoidocyathus cf. erbiensis (Zhuravleva, 1955).

Debrenne \& Zamarreño, p. 9-10, Figs. 6 y 7.

1985 Pycnoidocyathus erbiensis (Zhuravleva). Fonin, p.

104, P1. 15, fig. 4; P1. 16, fig. 1

1985 Archaeocyathus cf. grandis Yaroshevich. Debrenne

\& Gandin, p. 536, 538, P1. 2, fig. 1-3.

1992 Pycnoidocyathus erbiensis (Zhuravleva). Debrenne

\& Zhuravlev, p. 129

1997 Archaeocyathus erbiensis Zhuravleva. Zhuravleva et al., p. 162, Pl. 12, fig. 5.

v 2003. Pycnoidocyathus erbiensis (Zhuravleva, 1955).

Perejón \& Moreno-Eiris, p. 58-59, fig. 4, Lám. II, fig. 1b, Lám. V, Figs. 1b, 2-3.

Holotype. PIN 494, obr. 1000a.

Material. One thin section: SAL9/4-2/1.

Description. Solitary cup that in longitudinal section shows the outer wall with transverse undulations that do not affect the inner wall. Outer wall centripetal and inner wall with one single tube between every two tae- niae, short and directed upwardly. Variable interval with taeniae straight or wavy, sometimes thickened and with irregular structure towards the outer wall. Taeniae may have thickening by successive layers (stereoplasma) and are joined by synapticulae. The pores of the taeniae are arranged in rows diverging upward from the inner to the outer wall; and into the top of the cup. Occasionally vesicular tissue may appear on the outside of the intervallum.

Dimensions in $\mathrm{mm}$. Cup: D 12.96 to 17.05 ; I 3.32 to 6.47; N 42; ds 0.47 ; IK 0.26 to 0.19 ; RK 3.24 to 2.46 ; IC 1:7. Outer wall centripetal: $\mathrm{d} 0.08$ to 0.12 ; i 0.02 to 0.04 ; e 0.04 to 0.08 . Inner wall: $\mathrm{n} 1$; d 0.41 ; i 0.08 to 0.24 ; e 0.24 to 0.40 . Tube length 0.40 to 0.80 . Taeniae: $\mathrm{n} 6$; $\mathrm{d}$ $0.40 \times 0.56$ to $0.48 \times 0.80$; i 0.12 ; e 0.04 to 0.12 . Synapticulae: e 0.08 .

Discussion. The studied specimen is assigned to the genus Pycnoidocyathus based on the structure of the walls and intervallum. Due to its size, structural characteristics and coefficients, the specimen is included in the species P. erbiensis (Zhuravleva, 1955, Fig. 4), although the diameter of the present cup is smaller and the outer wall is corrugated, though not the inner wall. We also assign to this species the material from Tuva, described by Zhuravleva et al. (1967) as $P$. cf. erbiensis, although the central cavity is filled with secondary skeletal elements.

Geographic and stratigraphic distribution. RussiA: Kuznetsk Alatau: Khakassiya, Martyukhina Mountains. Chernokovski and Obruchev Horizon, Lower Cambrian. Sladkie Koren'ya Mountain, Sukhie Solontsy, Dolgiy Mys Mountain, Sochovaya Mountain, Sukhaya Erba River. Batenev Range. Altai: Katun River, Bi 'rch River. East Sayan: Uyar River, Obruchev Horizon, Toyonian, Lower Cambrian. Italy: Sardinia: Brèche Acquaresi, Nai Mountain, Onixeddu Mountain. Gonnesa Formation, Calcaire Ceroide Member. Toyonian, Lower Cambrian. SpaIn: Valdoré (León), V1 Section, 5C level, V2 Section, 2 level and Crémenes (León), CR1 Section, 1H level. Salce (León), Section Cerro Valdemarzón, 9 level. Láncara Formation, Early Bilbilian (Zone X), Stage 4, Series 2, Cambrian.

\section{Biostratigraphic and paleobiogeographic correlation with other Toyonian localities}

Archaeocyath-bearing microbialites had a wide distribution through the early Cambrian with a maximum development during the Atdabanian and Botomian. In the early Toyonian, all but a few species of archaeocyaths vanished, reducing the diversity dramatically (Perejón and Moreno-Eiris, 2006b). Such low-diversity assemblages are also recorded in the Spanish Toyonian archae- 
ocyathan buildups from the Cantabrian Mountains, where the archaeocyathan assemblage comprises four genera: Archaeocyathus, Pycnoidocyathus, Okulitchicyathus and Polythalamia. This assemblage characterizes the Spanish Zone X of Bilbilian age (Spanish stage), equivalent to the Toyonian age (Toyonian 1-2, Russian stage) according to Perejón and Moreno-Eiris (2006a), which corresponds to the Stage 4 within the Cambrian Series 2 (ICS, 2010). However, the first occurrence of Okulitchicyathus is in Zone I (early Ovetian age, Spanish stage). The Toyonian Iberian species are Archaeocyathus laqueus, Pycnoidocyathus erbiensis, Polythalamia sp., and Okulitchicyathus valdorensis (Debrenne and Zamarreño, 1970; Perejón and Moreno-Eiris, 2003).

The archaeocyathan assemblage of Sardinia consists of Angaricyathus tener, Archaeocyathus laqueus, A. kusmini, A. cumfundus and Pycnoidocyathus erbiensis (Debrenne and Gandin, 1985). The Angaricyathus, Archaeocyathus, and Pycnoidocyathus assemblage defines Sardinia assemblage 7 (S7), equivalent to Spanish Zone $\mathrm{X}$ according to Perejón and Moreno-Eiris, 2006a. Archaeocyathus is the only ubiquitous genus in the remainder of Gondwana: A. yichangensis occurs in the Tianheban Formation in China (Debrenne et al., 1991), and A. abacus and Ajacicyathus sp. appear in the Wirrealpa Limestone in Australia (Kruse, 1991). Additionally, other species of Archaeocyathus have been recorded outside of Gondwana in several regions (Siberian Platform, Altai Sayan, Transbaykalia and Laurentia) during Toyonian time.

The characteristic Toyonian taxa in other geographic areas outside of Gondwana are the following. In Laurentia we can distinguish, firstly, Labrador and western Newfoundland with Archaeocyathus atlanticus, Archaeosycon billingsi, Arrythmocricus kobluki, Metacyathellus simpliporus, Metaldetes profundus and Retilamina amourensis (Debrenne and James, 1981; Mansy et al., 1993), secondly, Greenland with Pycnoidocyathus pearylandicus, Tegerocyathus greenlandensis and Vologdinocyathus inesoni (Debrenne and Peel, 1986; Mansy et al., 1993), thirdly, the Great Basin with Archaeocyathus sp., Pycnoidocyathus sp. and Retilamina debrenneae (Savarese and Signor, 1989; Debrenne et al., 1990; Mansy et al., 1993), and finally, Sonora (Mexico) with Archaeocyathus sp. and Retilamina debrenneae (Debrenne et al., 1989; Mansy et al., 1993).

In the Siberia plate we can distinguish on the Siberian Platform: Irinaecyathus schabanovi, Archaeocyathus okulitchi, Tegerocyathus edelsteini and Vologdinocyathus borovikovi, (Osadchaya et al., 1979; Debrenne and Zhuravlev, 1992); in Altai Sayan and Kuznetsk Alatau: Tegerocyathus edelsteini, Vologdinocyathus borovikovi, $V$. expansivus, V. erbiensis, Claruscoscinus billingsi,
Irinaecyathus ratus, Archaeocyathus kusmini and Pycnoidocyathus erbiensis (Repina et al., 1964; Osadchaya et al., 1979; Zhuravleva et al., 1997); in Transbaikalia: Angaricyathus cyrenovi, Claruscoscinus billingsi (Yazmir et al., 1975; Debrenne and Zhuravlev, 1992).

During the Toyonian, the global maximum generic diversity was recorded in western Newfoundland (six genera), whereas the maximum diversity within Gondwana corresponds to the Cantabrian Mountains record (four genera). Only the ubiquitous genera Archaeocyathus and Pycnoidocyathus show a broad distribution in Laurentia, Siberian Platform and Gondwana in this age.

\section{Comparison with Toyonian Archaeocyath-rich facies from Gondwana}

As mentioned above, the archaeocyath-rich facies in the Cantabrian Mountains are low-diversity, centimeter-scale thrombolitic microbialite generated in a peritidal environment (Salce) and moderate-diversity calcimicrobialarchaeocyathan mounds (meter-scale) in a back-shoal environment (Esla nappe). The calcimicrobes were the main framebuilders of Toyonian bioconstructions, where Archaeocyathus could play a significant role forming branching modular framework. However, archaeocyaths were not only framebuilders, as they also colonized muddy environments, where they were subject to encrustation by calcimicrobes without producing true bioconstructions. In the Cantabrian Mountains, Pycnoidocyathus erbiensis occurs as solitary cups in the muddy deposits surrounding the small calcimicrobial mounds; however the isolated cups were not encrusted by calcimicrobes. On the other hand, in Sardinia, P. erbiensis appears in Renalcis boundstone and oncoid-bioclast grainstone, and they grew in a humid tropical Bahamian-type platform, though not forming bioconstructions or meadows according to Debrenne and Gandin (1985).

The archaeocyaths from the Chinese Tianheban Formation appear as small branching colonies and solitary cups. The colonies of stick-shaped cups surrounded by Epiphyton, Renalcis, Girvanella and Praulopora form small calcimicrobial mounds, whereas solitary cups occur in fine-grained sediments around the small mounds. The small mounds were developed in low-energy conditions, in a shallow water continental shelf in a warm climate (Debrenne et al., 1991). Gandin and Luchinina (1993) described the observed archaeocyath-calcimicrobe relationships in the Tianheban Formation. They detailed how the solitary archeocyath cups that occurred in wackestone facies are encrusted by Epiphyton, Renalcis and Girvanella (ERG assemblage) in the Huangshangong section, whereas the ERG calcimicrobial bioconstruc- 
tions with colonial archaeocyaths occurred in the Huangling section. Recently, Gandin \& Debrenne (2010) classified the small mounds from the Tianheban Formation as Type 2: "calcimicrobial thrombolitic framestone composed mainly of dominant Renalcis meadows associated with low diversity clusters of small regular or modular archaeocyaths". They described the Type 2 mounds associated with high-energy ooid and skeletal/ooid shoal complexes, where they formed as "isolated patch reefs or laterally continuos biostromal bodies in rather restricted back-shoal settings".

The Toyonian archaeocyath-bearing bioconstructions in the Wirrealpa Limestone in Australia are cyanobacterial-archaeocyathan-radiocyathan bioherms and cyanobacterial-archaeocyathan bioherms. These can attain up $3 \mathrm{~m}$ thick and $36 \mathrm{~m}$ in length and, in both cases, the primary framework corresponds to Epiphyton thrombolitic stromatolite framestone (Kruse, 1991). These bioherms were developed in subtidal, open marine but calm and shallow waters (Kruse, op. cit.).

Summarizing, the development of the Toyonian archaeocyath-rich facies in Gondwana was limited to small and low-diversity calcimicrobial-archaeocyathan mounds or solitary archaeocyaths in muddy sediments, with the exception of the Australian case, where meter-sized calcimicrobial-archaeocyathan bioherms were well developed. Regarding the palaeoenvironmental conditions, the archaeocyath bioconstructions colonized from peritidal environments to shallow subtidal open marine environments as well as in protected back-shoal settings.

\section{Conclusions}

The upper part of the lower member of the Láncara Formation shows a varied assemblage of microbial and grain-dominated facies that were deposited in an inner ramp during early Cambrian times. The water-sediment interface was prolifically colonized by microbial benthic communities that built up a variety of micro- and mesostructures such as microbial peloids, calcimicrobes, spongiostromata oncoids and a diversity of microbialites (massive and laminated peloidal fabrics, stromatolites and thrombolites).

In the Somiedo-Correcilla Subunit, the occurrence of patches with archaeocyath-rich thrombolitic microbialites is recorded for the first time at Salce. The archaeocyath-rich thrombolitic microbialites are mainly composed of mesoclots of shrub-like forms of Epiphyton (40\%) and branching modular archaeocyaths framework (25\%), while intermesoclot spaces are filled by peloidal micrite (10-20\%), small cavities (10\%) and pockets of skeletal remains.
The diverse occurrence of archaeocyath-rich bioconstructions in different sub-environments from the Cambrian record in the Cantabrian Mountains is adding new information to future paleogeographic reconstructions. In Salce, the patches grew in a peritidal environment in very shallow subtidal conditions and surrounded by cryptic massive microbialites and small lenticular pelletoid-rich intertidal bars, whereas at the Esla nappe, the archaeocyath-bearing microbialites formed larger patch reefs and grew between ooid shoal complexes. In both localities the archaeocyath-bearing microbialites were dominated by branching colonies of Archaeocyathus laqueus (VoLOGDIN, 1932), although archaeocyathan diversity was higher in the adjacent Esla nappe. On the other hand, Salce record resembles in part the lithofacies assemblage described from other localities (unit $\mathrm{C}$ in Fig. 2, and Table 1) but without either ooid and bioclastic shoal complex development or channelized siliciclastic deposits.

This new find increases the number of known archaeocyath localities in the upper member of the Láncara Formation in the Cantabrian Zone and allows us to assign an age of early Bilbilian (Spanish archaeocyathan Zone X), Stage 4, Series 2, Cambrian.

When the archaeocyaths decreased dramatically during the Toyonian, the maximum diversity was recorded in Laurentia. In Gondwana, the Cantabrian Mountains and Sardinia record the greatest numbers of genera (four and three respectively), and both areas have in common the occurrence of Archaeocyathus laqueus and Pycnoidocyathus erbiensis. In Gondwana, the archaeocyaths occurred as solitary cups and secondary framebuilders in low-diversity calcimicrobial-archaeocyathan bioconstructions (from centimeter-scale thrombolitic patches to large bioherms).

\section{Acknowledgements}

This work is a contribution to Projects CGL200612245BTE and CGL2009-07073BTE. We thank D. Carlos Alonso for his effective cooperation in the preparation and processing of fossil images for publication. We appreciate the helpful reviews of the manuscript by an anonymous reviewer and Dr. Álvaro (INTA).

\section{References}

Aitken, J.D. (1967): Classification and environmental significance of cryptalgal limestones and dolomites, with illustrations from the Cambrian and Ordovician of SW Alberta. Journal of Sedimentary Petrology 37, 1163-1178. doi:10.1306/74D7185C-2B21-11D7$8648000102 \mathrm{C} 1865 \mathrm{D}$.

Álvaro, J.J., Vennin, E. (1996): Tectonic control on Cambrian sedimentation in South-Western Europe. Eclogae geologicae Helvetiae 
89, 935-948.

Álvaro, J.J., Rouchy, J.M., Bechstädt, T., Boucot, A., Boyer, F., Debrenne, F., Moreno-Eiris, E., Perejón, A., Vennin, E. (2000a): Evaporitic constraints on the southward drifting of the western Gondwana margin during Early Cambrian times. Palaeogeography, Palaeoclimatology, Palaeoecology 160, 105-122. http://dx.doi. org/10.1016/S0031-0182(00)00061-4.

Álvaro, J.J., Vennin, E., Moreno-Eiris, E., Perejón, A. Bechstädt, T. (2000b): Sedimentary patterns across of the Lower-Middle Cambrian transition in the Esla nappe (Cantabrian Mountains, northern Spain). Sedimentary Geology 137, 43-63. http://dx.doi.org/10.1016/ S0037-0738(00)00134-2.

Aramburu, C. (1989): El Cambro-Ordovícico de la Zona Cantábrica (N.O. de España). Doctoral Thesis, Universidad de Oviedo: 350 p. (unpublished).

Aramburu, C., Arbizu, M., Bernárdez, E., Gozalo, R., Gutiérrez-Marco, J.C., Liñán, E. (2006): Excursión B. Paleontología y Estratigrafía del Paleozoico Inferior de Los Barrios de Luna. XXII Jornadas de la Sociedad Española de Paleontología. Servicio de Publicaciones de la Universidad de León: 75 p.

Aramburu, C., Truyols, J., Arbizu, M., Méndez-Bedia, I., Zamarreño, I., García-Ramos, J.C., Suárez de Centi, C. and Valenzuela, M. (1992): El Paleozoico Inferior de la Zona Cantábrica. In: GutiérrezMarco, J.C., Saavedra, J. \& Rábano, I. (eds.), Paleozoico Inferior de Ibero-América. Universidad de Extremadura, Badajoz-Cáceres: 397-421.

Bechstädt, T., Boni, M. (1989): Tectonic control on the formation of a carbonate platform: The Cambrian of Southwestwern Sardinia. In: P. D. Crevello, J.L. Wilson, J.F. Srag, J.F. Read (eds.), Controls on carbonate platform and basin development. SEPM Special Publication 44, 107-122. doi: 10.2110/pec.89.44.0107.

Bechstädt, T., Schledding, T. and Selg, M. (1988): Rise and fall of an isolated, unstable carbonate platform: The Cambrian of Southwestern Sardinia. Geologische Rundschau 77, 389-416. doi: 10.1007/ BF01832387.

Billings, E. (1861): New species of Lower Silurian fossils; on some new or little known species of Lower Silurian fossils from the Potsdam Group (Primordial zone). Geological Survey of Canada, Montreal: $24 \mathrm{p}$.

Bornemann, J.G. (1884): Berichte über die Fortsetzung seiner Untersuchungen Cambrischen Archaeocyathus- Formen und verwandler Organismen von der Insel Sardinien. Zeitschrift der Deutschen Geologischen Gessellschaft 36, 702-706.

Burne, R.V., Moore, L.S. (1987): Microbialites: Organosedimentary deposits of benthic microbial communities. Palaios 2/3, 241-254.

Chi, Y.S. (1940): Cambrian Archaeocyathinae from the Gorge District of the Yangtze. Bulletin of the Geological Society of China 20,121140. doi: 10.1111/j.1755-6724.1940.mp20002002.x.

Comte, P. (1937): La série cambrienne et silurienne du León (Espagne). Comptes Rendus de l'Academie des Sciences de Paris 204, 604-606.

Davies, G.R. (1970): Carbonate bank sedimentation, eastern Shark Bay, Western Australia. In: B.W. Logan, G.R Davies, J.F. Read, D.E Cebulski (eds.), Carbonate sedimentation and environments. American Association of Petroleum Geologists Memoir 13, 85-169.

Debrenne, F., Gandin, A. (1985): La formation de Gonnesa (Cambrien, SW Sardaigne): biostratigraphie, paléogeographie, paléoecologie des Archéocyathes. Bulletin de la Société Géologique de France 8 Série 1, 531-540.

Debrenne, F., Gandin, A., Rowland, S.M. (1989): Lower Cambrian bioconstructions in northwestern Mexico (Sonora). Depositional setting, paleoecology and systematic of archaeocyaths. Geobios 22, 137-195. doi: 10.1016/S0016-6995(89)80127-5.
Debrenne, F., Gandin, A., Gangloff, R.A. (1990): Analyse sédimentologique et paléontologique des calcaires organogènes du Cambrien inférieur de Battle Mountain (Nevada U.S.A.). Annales de Paléontologie (Vertébrés-Invertébrés) 76, 73-119.

Debrenne, F., Gandin, A., Zhuravlev, A.Y. (1991): Palaeoecological and sedimentological remarks on some Lower Cambrian sediments of Yangtse platform. Bulletin de la Societé Géologique de France $162,575-583$.

Debrenne, F., James, N.P. (1981): Reef-associated archaeocyathans from the Lower Cambrian of Labrador and Newfoundland. Palaeontology 24, 343-378.

Debrenne, F., Peel, J.S. (1986): Archaeocyatha from the Lower Cambrian of Peary Land, central North Greenland. Rapport Grønlands geologiske Undersøgelse 132, 39-50.

Debrenne, F., Zamarreño, I. (1970): Sur la découverte d'Archéocyathes dans le Cambrien du NW de l'Espagne. Breviora Geológica Asturica 14, 1-11.

Debrenne, F., Zhuravlev, A.Yu. (1992): Irregular Archaeocyaths. CNRS editions, Paris: 218 p.

Debrenne, F., Zhuravlev, A.Yu., Kruse, P.D. (2002): Class Archaeocyatha Bornemann, 1884. Bibliography of Class Archaeocyatha. In: J.N.A Hooper, R.W.M. Van Soest (eds.), Systema Porifera: A Guide to Classification of Sponges. Kluwer Academic-Plenum Publishers, New York: 1539-1699.

Flügel, E. (2004): Microfacies of carbonate rocks: analysis, interpretation and application. Springer Berlin Heidelberg New York: 976 p.

Fonin, V.D. (1985): Tenial'nye arkheotsiaty Altae-Sayansko skladchatoy oblasti [Taenial Archaeocyaths of the Altai-Sayan Fold Belt]. Trudy Paleontologicheskogo Instituta. Akademiya Nauk SSSR 209, 1-144. [in Russian].

Gandin, A., Debrenne, F. (2010): Distribution of the archaeocyathcalcimicrobial bioconstructions on the Early Cambrian shelves. $\mathrm{Pa}$ laeoworld 19, 222-241. doi: 10.1016/j.palwor.2010.09.010.

Gandin, A., Luchinina, V. (1993): Occurrences and environmental meaning of the Early Cambrian calcareous algae of the Tianheban Formation of China (Yangtze Area). In: F. Barattolo, P. De Castro, M. Parente, (eds.), Studies on Fossil Benthic Algae. Bollettino Società Paleontologica Italiana, Special Volume 1, 211-217.

Grant, R.E. (1836): Animal Kingdom. In: R.B. Todd (ed.). The Cyclopaedia of Anatomy and Physiology London: 1, 107-108.

Gürich, G. (1906): Les spongiostromides du Viséen de la Province de Namur. Memoires du Musée Royal d'Historie Naturelle de Belgique $3,1-55$

Hinde, C.J. (1889): On Archaeocyathus Billings, and on other genera, allied to or associated with it, from the Cambrian strata of North America, Spain, Sardinia, and Scotland. Quarterly Journal of Geological Society of London 45, 125-148. doi:10.1144/GSL. JGS.1889.045.01-04.10.

International Commission on Stratigraphy. (2010): International Stratigraphic chart. http://www.stratigraphy.org/column.php?id=Chart/ Time Scale

Julivert, M. (1967): La ventana tectónica del río Color y la prolongación septentrional del manto del Ponga. Trabajos de Geología $1,1-26$.

Julivert, M. (1971): Décollement tectonics in the Hercynian Cordillera of NW Spain. American Journal of Sciences 270, 1-29. doi: 10.2475/ajs.270.1.1.

Julivert, M., Pello, J., Fernández, L. (1968): La estructura del manto de Somiedo (Cordillera Cantábrica). Trabajos de Geología 2, 1-43.

Krumbein, W.E., Cohen, Y. (1977): Primary production, mat formation and lithification: contribution to oxygenic and facultative anoxygenic cyanobacteria. In: E. Flügel (ed.), Fossil Algae. Springer, Berlin: 37-56. 
Kruse, P.D. (1991): Cyanobacterial-archaeocyathan-radiocyathan bioherms in the Wirrealpa Limestone of South Australia. Canadian Journal Earth Sciences 28, 601-615. doi: 10.1139/e91-052.

Logan, B.W., Semeniuk, V. (1976): Dynamic metamorphism; process and products in Devonian carbonate rocks: Canning Basin, Western Australia. Geological Society of Australia Special Publication 6, $138 \mathrm{p}$.

Lotze, F. (1945): Zur Gliederung der Varisciden der Iberischen Meseta. Geotektonische Forschungen 6, 1-12.

Mansy, J.L., Debrenne, F., Zhuravlev, A.Yu. (1993): Calcaires à archéocyathes du Cambrien Inférieur du nord de la Colombie Britannique (Canada). Implications paléogéographiques et précisions sur l'extension du continent Américano-Koryakien. Géobios 26, 643683. http://dx.doi.org/10.1016/S0016-6995(93)80047-U.

Müller-Jungbluth, W.U., Toschek, P.H. (1969): Karbonatsedimentologische Arbeitsgrundlagen (Begriffe, Erläuterungen, Hinweise). Veröffentlinchungen der Universität Innsbruck, Alpenkundliche Studien 8, 1-32.

Oele, E. (1964): Sedimentological aspects of four Lower Palaeozoic Formations in the northern part of the province of Leon (Spain). Leidse Geologische Mededelingen 30, 1-99.

Okulitch, V.J. (1935): Cyathospongia - a new class of Porifera to include the Arcaheocyathinae. Transactions of the Royal Society of Canada Ser. 3, Sect. IV 29, 75-106.

Osadchaya, D.V., Kashina, L.N., Zhuravleva, I.T., Borodina, N.P. and Boyarinov, A.S. (1979): Lower Cambrian Stratigraphy and Archaeocyaths of the Altai-Sayan Fold Belt, Nauka Moscow: 216 p. [in Russian].

Perejón, A., Moreno-Eiris, E. (2003): Arqueociatos del Bilbiliense (Cámbrico Inferior) del manto del Esla, Cordillera Cantábrica, Norte de España. Boletín de la Real Sociedad Española de Historia Natural. Sección Geológica 98, 51-71.

Perejón, A., Moreno-Eiris, E. (2006a): Biostratigraphy and paleobiogeography of the archaeocyaths on the south-western margin of Gondwana. Zeitschrift der Deutschen Gesellstchaft für Geowissenchaften 157, 611-627. http://dx.doi.org/10.1127/18601804/2006/0157-0611.

Perejón, A., Moreno-Eiris, E. (2006b): Arqueociatos de España: Bioconstrucciones y puesta al día de la sistemática y la bioestratigrafía. Boletín de la Real Sociedad Española de Historia Natural. Sección Geológica 101, 105-145.

Perejón, A., Moreno-Eiris, E., Bechstädt, T., Menéndez, S. (2007): Nuevos datos de arqueociatos en la Cordillera Cantábrica. In: J.C. Braga, A. Checa, M. Company (eds.), XXIII Jornadas de la Sociedad Española de Paleontología. Libro de Resúmenes. Granada, Instituto Geológico y Minero de España y Universidad de Granada: p. 175-176.

Pérez-Estaún, A., Bastida, F., Alonso, J.L., Marquínez, J., Aller, J., Alvarez-Marrón, J., Marcos, A., Pulgar, J.A. (1988): A thin-skinned tectonics model for an arcuate fold and thrust belt: the Cantabrian Zone (Variscan Ibero-Armorican Arc). Tectonics 7, 517-537. doi:10.1029/TC007i003p00517.

Peryt, T.M. (1981): Phanerozoic oncoids -an overview. Facies 4, 197 214. doi: $10.1007 / \mathrm{BF} 02536588$.

Repina, L.N., Khomentovsky, V.V., Zhuravleva, I.T., Rozanov, A.Yu. (1964): Biostratigrafiya nizhnego kembriya Sayano-Altayskoy skladchatoy oblasti. [Lower Cambrian Biostratigraphy of the AltaiSayan Fold Belt]. Izdatelstvo Nauka. Moscow: 365 p. [in Russian].

Rodríguez Fernández, L.R., Barba, P., Bardají, T., Bravo Fernández, I., Fernández, L.P., Galán, L., Gallastegui, G., Gutiérrez Clavero, M., Heredia, N., López Díaz, F., Martinez Álvarez, J.A., Paniagua, A., Salvador González, C., Silva, P.G., Suárez Rodríguez, P.I., To- rres Alonso, M., Toyos, J.M., Villa, E. (1990): Mapa Geológico de España, E. 1/ 50.000, 2 a serie, no. 102 (Los Barrios de Luna). Instituto Tecnológico GeoMinero de España, Madrid: 130 p.

Russo, A., Bechstädt, T. (1994): Evolución sedimentológica y paleogeográfica de la formación Vegadeo (Cámbrico Inferior-Medio) en la zona entre Visuña y Piedrafita do Laurel (Lugo, NO de España). Revista de la Sociedad Geológica de España 47, 299-310.

Savarese, M., Signor, P.W. (1989): New Archaeocyathan occurrences in the Upper Harkless Formation (Lower Cambrian of western Nevada). Journal of Paleontology 63, 539-549.

Shapiro, R.S. (2000): A comment on the systematic confusion on thrombolites. Palaios 15, 166-169. doi: 10.1669/0883-1351(2000) 015<0166:ACOTSC $>2.0$. CO;2.

Shinn, E.A. (1968): Practical significance of birdseyes structures in carbonate rocks. Journal of Sedimentary Petrology 38, 215-223. doi: 10.1306/74D7191F-2B21-11D7-8648000102C1865D.

Taylor, T.G. (1910): The Archaeocyathinae from the Cambrian of South Australia with an account of the morphology and affinities of the whole class. Memoirs of the Royal Society of South Australia 2, 55-188.

Tebbutt, G.E., Conley, C.D., Boyd, D.W. (1965): Lithogenesis of a distinctive carbonate rock fabric. In: Parker, R.B. (ed.). Contributions to geology 4, 1-12.

Van der Meer Mohr, C.G. (1969): The stratigraphy of the Cambrian Láncara Formation between the Luna river and the Esla river in the Cantabrian Mountains Spain. Leidse Geologische Mededelingen 43, 233-316.

Vera, J.A. (ed.). (2004): Geología de España. Sociedad Geológica de España e Instituto Geológico y Minero de España, Madrid: 884 p.

Vologdin, A.G. (1932): Arkheotsiaty Sibiri. Vypusk 2. Fauna kembriyskikh izvestnyakov Altaya. [Siberian archaeocyaths. Issue 2: Fauna from Cambrian Limestone from Altai], Gosudarstvennoe NauchnoTekhnicheskoe Geologo-Razvedochnoe, Moscow-Leningrad: 1-71 [in Russian], 73-95 [in English].

Vologdin, A.G. (1937): Arkheotsiaty i rezultaty ikh izucheniya v SSSR (kratkaya svodka). [Archaeocyaths and the results of their study in USSR (a bried review)]. Problemy Paleontologii 2/3:,453481 [in Russian], 481-500 [in English].

Vologdin, A.G. (1940): Podtip Arkheotsiaty (Archaeocyatha). [Subfillum archaeocyaths (Archaeocyatha)]. In: Atlas Rukovodyashchikh Form Iskopaemykh Faun SSSR. Tom. 1: Kembriy. [Atlas of the index species of the USSR Fossil Fauna. Vol. 1. Cambrian]. A.G. Vologdin (ed.). Gosgeolizdat. Moscow: 24-97 [in Russian].

Wotte, T. (2009): Re-interpretation of a Lower-Middle Cambrian West Gondwanan ramp depositional system: a case study from the Cantabrian Zone (NW Spain). Facies 55, 473-487. doi: 10.1007/ s10347-008-0174-0.

Yazmir, M.M., Dalmatov, B.A., Yazmir, I.K. (1975): Atlas fauny i flory paleozoya i mezozoya Buryatskoy ASSR. Paleozoy [Atlas of the fauna and flora of the Palaeozoic and Mesozoic of the Buryatian ASSR. Palaeozoic]. Nedra, Moscow: 184 p. [in Russian].

Zamarreño, I. (1972): Las litofacies carbonatadas del Cámbrico de la Zona Cantábrica (NW. España) y su distribución paleogeográfica. Trabajos de Geología 5, 1-118.

Zamarreño, I. (1975): Peritidal origin of Cambrian carbonates in northwest Spain. In: R.N. Ginsburg, (ed.), Tidal Deposits: a case book of recent examples and fossil countparts. Springer Verlag, Berlin Heidelberg: 323-332.

Zamarreño, I. (1978): Tipos y distribución de facies en el nivel carbonatado del Cámbrico de España. In: Geología de la parte norte del macizo ibérico. Cuadernos del Seminario de Estudios Cerámicos de Sargadelos: Edición homenaje a Isidro Parga Pondal 27, 289-311. 
Zamarreño, I. (1981): Lower Cambrian stromatolites from northwest Spain and their palaeoenvironmental significance. In: C. Monty (ed.), Phanerozoic Stromatolites. Springer-Verlag Berlin, Heidelberg: 5-18.

Zamarreño, I., Julivert, M. (1967): Estratigrafía del Cámbrico del Oriente de Asturias y estudio petrográfico de las facies carbonatadas. Trabajos de Geología 1, 135-163.

Zhuravleva, I. T. 1955. Arkheotsiaty kembriya vostochnogo sklona Kuznetskogo Ala-Tau [Cambrian archaeocyaths of the eastern flank of the Kuznetsk Ala-Tau]. Paleontologicheskiy Institut, Akademiya Nauk SSSR, Trudy 56:5-56, 6 fig., 1 tab., pl. 1-6. [in Russian].

Zhuravleva, I.T. (1960): Arkheotsiaty sibirskoy platformy. [Archaeo- cyaths of the Siberian Platform]. Akademiya Nauk SSSR. Moscow: 344 p. [in Russian].

Zhuravleva, I.T., Konyaeva, I.A., Osadchaya, D.V., Boyarinov, A.S. (1997): Biostratigraphy of the Kiya River section Early Cambrian Archaeocyaths and spicular Sponges from the Kiya River section (Kuznetsk Alatau). Annales de Paléontologie (Vertèbre-Invertèbre) 83(1), 3-92; 83(2), 115-200.

Zhuravleva, I.T., Zadorozhnaya, N.M., Osadchaya, D.V., Pokroskaya, N.V., Rodionova, N.M., Fonin, V.D. (1967): Fauna nizhnego kembriya Tuvy (opornyy razrez $r$. Shivelig-Khem). [Lower Cambrian fauna of Tuva (the Reference Section of the Shivelig Khem River)]. Nauka. Moscow: 180 p. [in Russian]. 